\title{
The Effect of Compensation on Employees' Performance: A Case of a Technical University in Ghana
}

\author{
E. Ohene Afriyie*, A. Twumasi, E. Sarpong, L. Opare Darko \\ Lecturers Accra Technical University P O Box 561 Accra
}

*Corresponding Author: E. Ohene Afriyie, Senior Lecturer, Accra Technical University P O Box GP 561 Accra, Ghana

\begin{abstract}
The study investigated the effect of compensation on employee's performance Accra Technical University: Ghana. Descriptive survey design was used for the investigation. A simple random sampling technique was used to sample 40 respondents out of a total population of 57 Administrators of which 35 responded to the Twenty-item questionnaire. Frequency tables were used to present the responses. The main conclusions were that administrators were not attracted by the monetary aspect of compensation but rather management sensitivity to their needs. We also find that, housing loan and accommodation are the most crucial needs. The recommendation was that Management should create another form of set-off package alongside with the one in the condition of service to encourage workers to put up their best.
\end{abstract}

Keywords: Administrator; Compensation; Human Resource Management; Employees' Performance.

\section{INTRODUCTION}

Organisations and institutions all over the world need the services of other individuals to make it productive [1], [2]. The success or failure of such organization and systems depend mainly on the ability, intelligence or the character of its workers that are found there [3]. Human Resource Management (HRM) has never been as significant as it is today. Companies want to attract, retain and motivate brains to meet objectives. Today, Human resource is regarded as one of every company's assets [4], so they need to be effective and more managed. One of the tools companies use to attract, retain and motivate its people is Compensation Management [5].

According to [6], [7] one essential of HRM is compensation. Payment, reward, advantage, opportunity are all meanings of compensation and in retaining key executives who can help a company achieve growth and prosperity, all these definitions must come into play [8], [9] . Organisations often do not realize their full growth potential because they have yet to develop an incentive program that motivates employees [10], [11]. Although "compensation" in the business world is often a euphemism for "more money [12], most executives would likely agree that it takes more than a hefty paycheck to keep them satisfied [13].

As Thomas Alva Edison once said, "what you are will show in what you do" [14, p.254]. These words ring loud and genuine within a company's structure and illustrate the importance of matching the skill sets and talents of key executives to their appropriate role within the organisation. Ideal compensation system will have the positive impact on the efficiency and results produced by employees [15]. It also encourages the employee to perform better and achieve the objectives set [16].

\section{RESEARCH OBJECTIVE}

The study seeks to investigate the effect of compensation on the performance of administrators' in Accra Technical University. To achieve this aim, the following objectives are set.

1. Identity the compensation packages available to administrators of Accra Technical University;

2. Examine the compensation strategies that University use to motivate employees;

3. Assess how the University measures employee's performance;

4. Examine the relationship between compensation practices and performance of the administrators in Accra Technical University. 


\section{RESEARCH QUESTIONS}

To achieve the stated objectives the following questions were asked:

1. What are the compensation packages available to administrators of Accra Technical University?

2. What are the compensation strategies that University uses to motivate employees?

3. How does the University measure employee's performance?

4. What is the relationship between compensation practices and performance of the administrators in Accra Technical University?

\section{LiTERATURE REVIEW}

According to Geralyn, as cited by [4], compensation is the form of pay or incentive given to an employee for performing services for an employer. It comprises wages, salaries, incentives, or bonuses. An employee is compensated based on his/her skills, knowledge, experience, and education [17], [18]. The compensation package offers to employees affects the organisation's recruitment rate, retention rate, and employee satisfaction. Several federal laws change the compensation that companies offer [19]. A business owner should understand the importance of set-off and the prevailing laws to remain competitive in the market [20]. In a study of managers from Taiwan and Cambodia, concluded that compensation had an active and significant influence on non-financial and financial dimensions of organizational performance [21].

\section{COMPENSATION STRATEgies}

According to [22], compensation is the form of pay or incentive given to an employee for performing services for an employer. It is often based on wages, salaries, incentives, or bonuses. [23], view compensation as an outcome in the exchange among employees and themselves as an entitlement for being an employee of the organization or as a reward for a job well done. It does not necessarily mean that anyone who gets paid has done the job well. Employees may not live up to expectation but can still get paid because of the Trade Union Congress (TUC) laws and regulations. An employee is compensated based on his/her skills, knowledge, experience, and education [24], [25]. [26], stress that compensation is particularly an important topic because often compensation significantly affects recruiting and retention efforts of a firm [27], if organizations cannot pay applicants enough, then they cannot recruit or retain critical skills or knowledge needed to operate efficiently and more. Compensation is also the second most investigated topic in human resource management [28].

Compensation is viewed from total rewards perspective as it encompasses psychological rewards, learning opportunities, and recognition in addition to monetary rewards in the forms of base pay and incentives [29]. In compensation practices, firms with a more entrepreneurial orientation tend to base pay rates on market comparisons more so than on internal equity concerns [30].

The strong financial package must be enough to provide incentives for employees and encourage them to stay with the firm [27]. They further asserted that the feelings of the employees also influence the performance of the company; the employees' morale will determine the success or failures [31].

Compensation is one of many Human Resource (HR) tools that organizations use to manage their employees and for an organization to receive its money's worth and motivate and retain skilled employees, it needs to ensure that its compensation system is not an island by itself [18]. But also, it is important for an organization to link compensation to its overall goals and strategies; it is significant that its compensation system aligns with its HR strategy [32]. It thus means that the compensation scheme in an organization is an HR strategy that is meant to motivate workers to deliver.

\section{Motivation}

Motivation is expected to accomplish work productivity [33], [34] and job satisfaction and also the strongest motivation is what people value, but they lack [35], [36]. However, [37], [38]believe that employees with high levels of motivation tend to work as compared to employees with low levels of motivation. [39], opines that compensation is not first about money but also concerned with that nonfinancial compensation which provides intrinsic and extrinsic motivation. Therefore, workers are not motivated by monetary pay alone but other things that come in addition to the pay [40], [41]. If an 
organization can identify these motivators and reward the workforce with them, it will induce them to perform [42].

Business should therefore offer different incentives to workers to help them fulfil each need to turn and progress up the hierarchy [43]. Managers should also recognize that motivations of workers needs are not the same [44], they move in the different hierarchy and not at the same pace. It is, therefore, important to give workers a slightly different set of incentives [45].

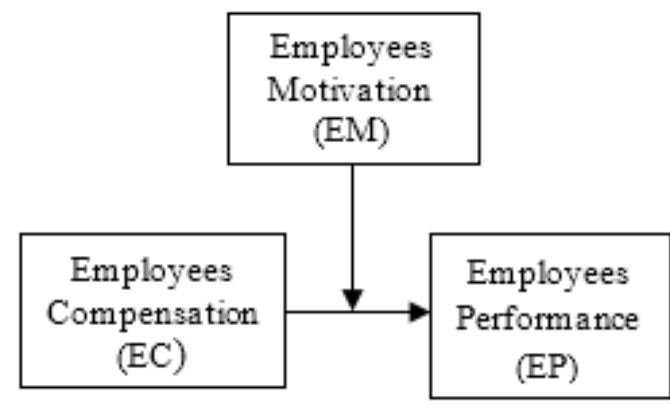

Fig1.Conceptual Model

What is the effect of EC on EP?

How is the relationship between EC and EP affected by EM?

\section{RESEARCH DESIGN}

The research design that was used for the study is survey. [46, p.23], also define survey as "The broad distribution of either questionnaires or interviews designed to get certain data from people". To achieve the set objectives, quantitative method came up as the appropriate strategy. [47] Quantitative research usually emphasisesgeneralizations, where statistics inference of results and conclusions are extrapolated and made applicable to an entire population. Primary data was collected from a sample of 40 Administrators who were randomly selected. They were selected from a list given by the Manageress of Human Resource of Accra Technical University. A total of 35 filled questionnaires received with a response rate of 87.5 percent. Unfortunately, the five that did not fill the questionnaire at that time were on leave.

\section{Methodology}

Research design that was used for the study is descriptive in the form of survey. Survey can be defined as the broad distribution of either questionnaires or interviews designed to get certain data from people [48], [49], [50].To achieve the set objectives, the quantitative method came up as the appropriate strategy. [51]. [52] [47], quantitative research usually emphasizes generalizations, where statistics inference of results and conclusions are extrapolated and made applicable to an entire population [53]. Primary data was collected from a sample of 40 Administrators who were randomly selected. They were selected from a list given by the Manageress of Human Resource of Accra Technical University. A total of 35 filled questionnaires received with a response rate of 87.5 percent. Unfortunately, the five that did not fill the questionnaire at that time were on leave.

\section{RESULTS}

Out of the 40 questionnaires, distributed to Administrators of Accra Technical University, 35 responded to the survey. This represents $87 \%$ a response rate for which is much appreciable. A description of the general features of Administrators is presented in Table 1 through to Table 4 and discussed in this section the following are demographic characteristics of respondents

TABLE1. GENDER OF ADMINISTRATORS

\begin{tabular}{|l|l|l|}
\hline Gender & Frequency & Percent \\
\hline Male & 5 & 14.3 \\
\hline Female & 30 & 85.7 \\
\hline Total & $\mathbf{3 5}$ & $\mathbf{1 0 0 . 0}$ \\
\hline
\end{tabular}

It can be observed that most of the respondents were female. This is because 30 respondents representing (85.7\%) of the Administrators were females. Only 5 administrators (14.3\%) were male. This support the idea that most administrators are females. 
TABLE2. AGE GROUP OF ADMINISTRATORS

\begin{tabular}{|l|l|l|}
\hline Age Group & Frequency & Percent \\
\hline $21-30$ years & 8 & 22.8 \\
\hline $31-40$ years & 21 & 60.0 \\
\hline $41-50$ years & 5 & 14.3 \\
\hline $51-60$ years & 1 & 2.9 \\
\hline Total & $\mathbf{3 5}$ & $\mathbf{1 0 0 . 0}$ \\
\hline
\end{tabular}

It can be seen from table 2 that 8 Administrators repesentting (22.8\%) were between the ages of 21 and 30 , (about 74\%) of the Administration were within the 31 to 50 age brackets with most $(2.9 \%)$ of them being with $51-60$ years. This implies that the general employees of the Administrator in Accra Technical University, Accra were quite youthful and this indicate that University has calibre of staff that will be in the position to assist in achieving its goals in the next twenty years.

TABLE3. EDUCATIONAL LEVEL

\begin{tabular}{|l|l|l|}
\hline Educational Level & Frequency & Percent \\
\hline Tertiary & 32 & 91.4 \\
\hline Other & 3 & 8.6 \\
\hline Total & $\mathbf{3 5}$ & $\mathbf{1 0 0 . 0}$ \\
\hline
\end{tabular}

On Educational level of Administrators, expectedly, as about (8.6\%) of the Administrators did not mention their educational level. Furthermore, $(91 \%)$ of the Administrator had had a tertiary level of experience in education. This implies that the Accra Technical University had, appreciably, skilled employees.

TABLE4. WORKING EXPERIENCE

\begin{tabular}{|l|c|c|}
\hline Working Experience & Frequency & Percent \\
\hline A similar position & 20 & 57.1 \\
\hline None & 11 & 31.4 \\
\hline Banker and others & 4 & 11.4 \\
\hline Total & $\mathbf{3 5}$ & $\mathbf{1 0 0 . 0}$ \\
\hline
\end{tabular}

In the case of working experience, 20 Administrator representing (57\%) had been in a similar position or job before coming to Accra Technical University. Eleven Administrators representing (31\%) had never had experience before joining the University, and 4 Administrators representing (11\%) had been bankers and others. The result indicates that most Administrators employed by the University had already gotten experience of the field.

\section{COMPENSATION}

This section looks at the compensation practice of Accra Technical University: Ghana. The results of the analysis are presented in Table 5 through 8. It is clear that a total of 35 administrators responded to the questionnaire.

TABLE5. WORKING COMPENSATION

\begin{tabular}{|l|l|l|}
\hline Working Compensation & Frequency & Percent \\
\hline Salaries paid for service provided & 18 & $27.3 \%$ \\
\hline Salaries and fringe benefits for service provided & 20 & $30.3 \%$ \\
\hline Fringe benefits and other rewards for service provided & 28 & $42.4 \%$ \\
\hline Total & 66 & $100.0 \%$ \\
\hline
\end{tabular}

It can be observed from Table 5 that most (about 42.2\%) of Administrators indicated that they understand compensation being fringe benefits and other rewards for service provided, $30.3 \%$ also understand compensation being salaries and fringe benefits for service provided. A little over a quarter (about 27\%) of them indicated compensation is Salaries paid for service provided. This affirms the study of [4] that compensation is the form of pay or incentive given to an employee for performing services for an employer. It is often based on wages, salaries, incentives, or bonuses.

TABLE6. TYPES OF COMPENSATION

\begin{tabular}{|l|l|c|}
\hline Types of Compensation & Frequency & Present \\
\hline Risk allowance & 18 & $37.5 \%$ \\
\hline Overtime allowance & 21 & $43.8 \%$ \\
\hline
\end{tabular}


The Effect of Compensation on Employees' Performance: A Case of a Technical University in Ghana

\begin{tabular}{|c|c|c|}
\hline Shift allowance & 3 & $6.2 \%$ \\
\hline Responsibility allowance & 6 & $12.5 \%$ \\
\hline Total & 48 & $100.0 \%$ \\
\hline
\end{tabular}

It can be seen from Table 6 that about $43.8 \%$ wanted overtime allowance, 37.5\% preferred risk allowance, $12.2 \%$ wanted responsibility allowance, and $6.2 \%$ wanted shift allowance. It can be seen that most Administrators did not want to shift allowance as compared to overtime allowance.

TABLE7. FORMS OF BENEFIT

\begin{tabular}{|l|l|l|}
\hline Forms of Benefits & Frequency & Percent \\
\hline Social security & 21 & $31.8 \%$ \\
\hline Accommodation & 10 & $15.2 \%$ \\
\hline Health care & 17 & $25.8 \%$ \\
\hline Transportation & 18 & $27.3 \%$ \\
\hline Total & $\mathbf{6 6}$ & $\mathbf{1 0 0 . 0 \%}$ \\
\hline
\end{tabular}

Table 7 shows the forms of benefits Administrators enjoy in Accra Technical University. $31.8 \%$ said social security. $27 \%$ of Administrators said they are given transportation allowance. $25.8 \%$ received health care while $15.2 \%$ were given accommodation. The result shows that most Administrators do not enjoy accommodation benefits.

TABLE8. ACCESS TO BENEFITS

\begin{tabular}{|l|l|l|}
\hline Access to Benefits & Frequency & Percent \\
\hline Promotion & 23 & $40.4 \%$ \\
\hline Annual Increment & 7 & $12.3 \%$ \\
\hline Provident fund & 24 & $42.1 \%$ \\
\hline In-service Training & 3 & $5.3 \%$ \\
\hline Total & $\mathbf{5 7}$ & $\mathbf{1 0 0 . 0 \%}$ \\
\hline
\end{tabular}

Table 8 shows about $42 \%$ said that the provident fund would help them perform. Forty preferred promotion. While about $12 \%$ want an annual increment of salary, it can be deduced from the table that the administrator went provident fund or promotion to help them perform [54\}.

\section{Motivation}

The motivation of Administrators of Accra Technical University based on the assessment of their performance is presented and discussed in this section. These are addressed by looking at the evaluation of salaries and fringe benefits available to motivate to deliver, felt the need, satisfaction of the condition of service.

TABLE9. SALARY AND FRINGE BENEFITS

\begin{tabular}{|l|l|l|}
\hline Salaries and Fringe Benefit & Frequency & Percent \\
\hline Highly enough & 2 & 5.7 \\
\hline Enough & 6 & 17.1 \\
\hline Not enough & 25 & 71.4 \\
\hline Not enough at all & 2 & 5.7 \\
\hline Total & $\mathbf{3 5}$ & $\mathbf{1 0 0 . 0}$ \\
\hline
\end{tabular}

It can be seen from table 9 that about (71\%) indicated that salary and fringe benefit they earned was not enough. Also, about (5.7\%) said it is highly enough and also not enough at all. Seventeen percent said salary and fringe benefit given to administrators are not enough. The result indicates that most of the Administrators were not satisfied with their salaries and fringe benefits and it cannot motivate them to deliver [55].

TABLE10. FACTORS THAT MOTIVATE EMPLOYEES

\begin{tabular}{|l|l|l|}
\hline Motivation Factors & Frequency & Percent \\
\hline High monetary reward & 18 & $23.4 \%$ \\
\hline A very good succession plan & 24 & $31.2 \%$ \\
\hline Management sensitivity to employees needs & 35 & $45.5 \%$ \\
\hline Total & $\mathbf{7 7}$ & $\mathbf{1 0 0 . 0 \%}$ \\
\hline
\end{tabular}

The results of table 10 indicate that about (46\%) of Administrators reported that the management sensitivity motivated them to their needs. Also, (31\%) stated that an excellent succession plan drove them. Twenty-three respondents said that high monetary reward drove them. [31], opines that 
compensation is not first about money [56] but also concerned with that non-financial compensation which provides intrinsic and extrinsic motivation. The result indicates that monetary reward does not motivate administrators, but management sensitivity to employees needs [57].

TABLE11. NEEDS OF ADMINISTRATORS

\begin{tabular}{|l|c|c|}
\hline Felt need & Frequency & Percent \\
\hline Accommodation & 14 & $40.0 \%$ \\
\hline Transportation & 5 & $14.3 \%$ \\
\hline Housing loan & 13 & $37.1 \%$ \\
\hline Car loan & 3 & $8.6 \%$ \\
\hline \multicolumn{1}{|c|}{ Total } & $\mathbf{3 5}$ & $\mathbf{1 0 0 . 0 \%}$ \\
\hline
\end{tabular}

From table 11 it can be observed that (40\%) indicated that administrators want accommodation. Fourteen percent need Transportation. About (37\%) indicated that they need Housing loan and about (9\%) need the Car loan. The result suggests that Administrators need accommodation and housing loan the most.

TABLE12. EFFECT ON PERFORMANCE AT WORK

\begin{tabular}{|l|l|l|}
\hline Needs that Affect Performance & Frequency & Percentage \\
\hline It will give me peace of mind by not renting accommodation & 13 & $35.1 \%$ \\
\hline It will facilitate my coming to work & 9 & $24.3 \%$ \\
\hline It calms nerves down as I know I will own a house sooner or later & 10 & $27.0 \%$ \\
\hline It will make me mobile and help me respond to call to work readily & 5 & $13.5 \%$ \\
\hline Total & $\mathbf{3 7}$ & $\mathbf{1 0 0 . 0 \%}$ \\
\hline
\end{tabular}

Table 12 reports the effect of performance at work. Thirteen respondents representing $(35.1 \%)$ believe that when giving accommodation will give than peace of mind. Twelve administrators reported that when giving housing loan it will help them to owe their own and it will calm nerves down. Nine administrators are of the view that when giving transportation it will facilitate their coming to work on time as compared to how they go to work. Five respondents suggested that it will make them mobile when given car loan to purchase theirs will help them respond to work readily.

TABLE13. CONDITION OF SERVICE

\begin{tabular}{|l|l|l|}
\hline Condition of service & Frequency & Percent \\
\hline Satisfied & 6 & $17.1 \%$ \\
\hline Quite Satisfied & 25 & $71.4 \%$ \\
\hline Not Satisfied at all & 4 & $11.4 \%$ \\
\hline Total & $\mathbf{3 5}$ & $\mathbf{1 0 0 . 0 \%}$ \\
\hline
\end{tabular}

From table 13, it can be observed that most of the Administrators were quite satisfied with their condition of services. Four respondents representing (11.4\%) opined that they were satisfied or not satisfied at all. The result suggests that $(88.5 \%)$ of Administrators in the Accra technical university are somewhat satisfied with the condition of service. This means the majority are satisfied with the university condition of service.

TABLE14. CAUSES OF WORKERS AGITATION

\begin{tabular}{|l|l|l|}
\hline Causes of Agitation & Frequency & Percent \\
\hline Low remuneration & 27 & $35.5 \%$ \\
\hline Management perks & 22 & $28.9 \%$ \\
\hline The insensitivity of management to workers felt needs & 27 & $35.5 \%$ \\
\hline Total & $\mathbf{7 6}$ & $\mathbf{1 0 0 . 0 \%}$ \\
\hline
\end{tabular}

From table 14, it can be seen that 27 respondents representing (35.5\%) respectively said low remuneration and insensitivity management to workers felt needs cause workers agitation. Twentytwo respondents representing (28.9\%) were on the view that workers agitation is caused by management perks. The result shows that there were diverse views about the causes of workers agitation, but low remuneration and insensitivity to works needs can cause workers agitation [58].

TABLE15. UNDERSTANDING OF EMPLOYEE PERFORMANCE

\begin{tabular}{|l|l|l|}
\hline Employee Performance & Frequency & Percent \\
\hline To meet deadline & 24 & $30.8 \%$ \\
\hline To deliver at work without excuses & 25 & $32.0 \%$ \\
\hline To meet set targets & 29 & $37.1 \%$ \\
\hline Total & $\mathbf{7 8}$ & $\mathbf{1 0 0 . 0 \%}$ \\
\hline
\end{tabular}


It can be seen from table 15 that about (37\%) of administrator understand employee performance been meeting set targets. Also about $(32 \%)$ understand it being able to deliver the work without excuses while $30 \%$ being meeting the deadline.

TABLE16. PERFORMANCE ASSESSMENT

\begin{tabular}{|l|l|l|}
\hline Responses & Frequency & Percent \\
\hline No & 27 & 77.1 \\
\hline Yes & 8 & 22.9 \\
\hline Total & $\mathbf{3 5}$ & $\mathbf{1 0 0 . 0}$ \\
\hline
\end{tabular}

Furthermore, table 16 reveals that most, about (77\%) of Administrators reported that their performances were not assessed. This means they were not aware of the criteria that University use to assess Administrators performance. Table 17 indicates the means of Assessing Employees' Performance.

TABLE17. MEANS ASSESSING EMPLOYEES' PERFORMANCE

\begin{tabular}{|l|l|l|}
\hline Responses & Frequency & Percent \\
\hline Rated on performance of your duties & 16 & $20.0 \%$ \\
\hline Based on key behaviours on the job & 12 & $15.0 \%$ \\
\hline Based on a written description of your strengths and weaknesses & 7 & $8.8 \%$ \\
\hline Based on the extent to which you have achieved targets & 12 & $15.0 \%$ \\
\hline Based on your own self-appraisal & 6 & $7.5 \%$ \\
\hline Based on appraisal by your peers & 4 & $5.0 \%$ \\
\hline Based on appraisal by supervisor/manager & 18 & $22.5 \%$ \\
\hline Compare your performance with those of other employees in similar positions & 5 & $6.2 \%$ \\
\hline Total & $\mathbf{8 0}$ & $\mathbf{1 0 0 . 0 \%}$ \\
\hline
\end{tabular}

Table 17 reveals that about $(22 \%)$ of the Administrators indicated that their performance were assessed based on appraisal by supervisors/manager; performance of duties. Twenty percent indicated the rated on performance of duties. Furthermore, $(15 \%)$ of Administrators respectively indicated that the assessment of their performance was based on key behaviours on the job and the extent to which they have achieved targets and eight percent believed it is based on a written description of your strengths and weaknesses. Six, five and four percent respectively said it is based on individual selfappraisal, comparism of performance with other employees in similar positions and appraisal by your peers. This implies that there are various means of assessing Administrators performance.

TABLE18. PERFORMANCE BEFORE COMPENSATION

\begin{tabular}{|l|l|l|}
\hline Responses & Frequency & Percent \\
\hline No & 13 & 37.1 \\
\hline Yes & 22 & 62.9 \\
\hline Total & $\mathbf{3 5}$ & $\mathbf{1 0 0 . 0}$ \\
\hline
\end{tabular}

Table 18 reveals that about $(63 \%)$ of the Administrators were of the view that they should perform before been compensated for a work done, while a little below $(37 \%)$ opined that they should be compensated for to perform a task. This indicates work should be done before compensation.

TABLE19.COMPENSATION BEFORE PERFORMANCE

\begin{tabular}{|l|l|l|}
\hline Responses & Frequency & Percent \\
\hline No & 26 & 74.3 \\
\hline Yes & 9 & 25.7 \\
\hline Total & $\mathbf{3 5}$ & $\mathbf{1 0 0 . 0}$ \\
\hline
\end{tabular}

Table 19 reveals that most of the Administrators (74\%) were of the view that they should not be compensated for before performing but rather perform before compensated and $(25 \%)$ said they should be compensated before performance. This shows that it is not compensation that leads to performance. The result indicates that compensations had the little but negative influence on performance because in government institutions, workers are paid monthly not on performance. It also shows that lack of compensations demotivates employees to give off their best according to the study.

\section{KEY FINDINGS}

From compensation of employees, the study revealed that administrators were not attracted by a monetary aspect of compensation [58] but rather management sensitivity to their needs. More also it 
was revealed that Administrators need housing loan and accommodation than any other things. Concerning motivation, from the responses, salary and fringe benefits they earned were not enough [59]. Administrators reported that they were motivated by the management sensitivity to employees' needs and excellent succession plan but not the high monetary reward [60]. They made it clear that they were somewhat satisfied with the condition of service. With regards to the performance of Administrators', it was found that they were of the view that they should not be compensated for before performing but rather after completion of the task before compensated. The study revealed that it is not compensation that leads to performance but rather performance result in compensation [61].

\section{CONCLUSION}

By the findings from the study, it can be concluded that from the responses, before compensating the workers their performance had to be assessed to determine deserving ones. However, on the contrary, it was found that the University was not evaluating the performances of their Administrators regularly. With regards to compensations of Administrators, it was seen that the University did not usually compensate their workers for good work done but, however, provided them with social security and healthcare as incentives for motivation.

\section{LiMitATION OF THE STUDY}

The drawing of the respondents from only Administrators of Accra Technical University impeded the degree of generalisation of the findings of the survey. Nevertheless, since the sample is more than half of the entire administrators, it can be argued that the conclusions of this study be applied to Administrator of Accra Technical University. The study also included that all Administrators irrespective of the number of years the respondent had worked with the institution was part of the study, and this is also likely to affect the results since new staff would not be in a position to have much experience with these practices. Some respondents reported to have little idea about the compensation practice and strategies use in motivation staff of Accra Technical University to perform; hence, their responses are likely not to be as pertaining to practice. Again, some respondents did not respond to all items on the questionnaire.

\section{RECOMMENDATION}

Following the research findings and conclusions, the following recommendations have been made as a guide to the University to improve its operation. New employees of Accra Technical University be given the condition of service and made them aware of compensation and motivation strategies available in the University. The condition of service should be put on the website of the Accra Technical University for workers to have easy access to it and read. Management of Accra Technical University should liaise with Government to use the GET-FUND to build accommodation facilities or look for a subsidised accommodation to house the employees. Management of Accra Technical University should compensate the best-performing worker for others to emulate and also create another form of compensation package alongside with the one in the condition of service to encourage workers to put up their best. Further research be conducted on the standard HRM practices such as recruitment and selection, health and safety, training and development and it effect on employee performance in Technical University.

\section{REFERENCES}

[1] Drucker, P. (2012). Management. Routledge.

[2] Fullan, M. (2012). Change forces: Probing the depths of educational reform. Routledge.

[3] Drucker, P. (2016). The effective executive. Routledge.

[4] Ohene Afriyie, E., Blankson G. A., \& Doumbia M. O. (2013). Effect of Human Resource Management Practices on the Performance of Small and Medium Hotels of Osu Klottey Sub-Metropolitan Assembly of Greater Accra. European Journal of Business and Management Vol.5, No.25, 2013.

[5] Noe, R. A., Hollenbeck, J. R., Gerhart, B., \& Wright, P. M. (2017). Human resource management: Gaining a competitive advantage. New York, NY: McGraw-Hill Education.

[6] Lai Wan, H. (2007). Human capital development policies: enhancing employees' satisfaction. Journal of European Industrial Training, 31(4), 297-322. 
[7] Milkovich, G. T. And Newman, J. M. (1999). Compensation, New York: Irwin/McGraw

[8] Armstrong, M. (2002). Employee reward. CIPD Publishing.

[9] Koontz, H. (2010). Essentials of management. Tata McGraw-Hill Education.

[10] \Austin, J., Stevenson, H., \& Wei-Skillern, J. (2012). Social and commercial entrepreneurship: same, different, or both?.Revista de Administração, 47(3), 370-384.

[11] Herzberg, F. (2008). One more time: how do you motivate employees?. Harvard Business Review Press.

[12] Moniz, J. (2010). The Basics for Building and Maintaining Incentive Plans at Smaller Firms. SAGE Publications.

[13] Buckingham, M., \& Coffman, C. (2014). First, break all the rules: What the world's greatest managers do differently. Simon and Schuster.

[14] Israel, P., \& Todd, R. (1998). Edison: A life of invention.

[15] Moniz, J. (2010). The Basics for Building and Maintaining Incentive Plans at Smaller Firms. Compensation \& Benefits Review, 42(4), 256-264.

[16] Koss, S. K. (2008). Solving the Compensation Puzzle. Pg. 21.

[17] Camuffo, A., Gerli, F., Borgo, S., \&Somià, T. (2009). The effects of management education on careers and compensation: A competency-based study of an Italian MBA programme. Journal of Management Development, 28(9), 839-858.

[18] Turner, K. L., \&Makhija, M. V. (2006). The role of organizational controls in managing knowledge. Academy of management review, 31(1), 197-217.

[19] Martocchio, J. J. (2011). Strategic compensation: A human resource management approach. Pearson Education India.

[20] Pathak, S., Hoskisson, R. E., \& Johnson, R. A. (2014). Settling up in CEO compensation: The impact of divestiture intensity and contextual factors in refocusing firms. Strategic Management Journal, 35(8), 1124-1143

[21] Chan, S. (2005). Relationship between HRM practices and the perception of organizational performance, roles of management style, social capital, and culture: comparison between manufacturing firms in Cambodia and Taiwan. 成功大學國際管理碩士在職進修專班 (IMBA) 學位論文, 1-181.

[22] Geralyn M. F. (2007). Human Resource Management Basic: Small verses Large Firm Practices. Virginia Hernandez. The University of Texas of Premium Basis.

[23] Brown, M. P., Sturman, M. C., \& Simmering, M. J. (2003). Compensation policy and organizational performance: The efficiency, operational, and financial implications of pay levels and pay structure. Academy of Management Journal, 46(6), 752-762.

[24] Allen, D. G., Bryant, P. C., \&Vardaman, J. M. (2010). Retaining talent: Replacing misconceptions with evidence-based strategies. Academy of management Perspectives, 24(2), 48-64.

[25] Vlachos, I. (2008). The effect of human resource practices on organizational performance: evidence from Greece. The International Journal of Human Resource Management, 19(1), 74-97.

[26] Rauf, A. M. (2007).HRM sophistication and Small and Medium Performance. A case of readymade garment manufacturers and exporters in Lohore. Patistan. Thesis .published.

[27] Allen, D. G., Bryant, P. C., \&Vardaman, J. M. (2010). Retaining talent: Replacing misconceptions with evidence-based strategies. Academy of management Perspectives, 24(2), 48-64.

[28] Henderson, L. N., \& Tulloch, J. (2008). Incentives for retaining and motivating health workers in Pacific and Asian countries. Human resources for health, 6(1), 18.

[29] Heneman, R. L., Tansky, J. W. \& Camp, S. M. (2000). Human resource management practices in small and medium-sized enterprises: Unanswered questions and future research perspectives. Entrepreneurship: Theory \& Practice, 25, 11-25.

[30] Herzberg, M, B. \& Snyderman, B. B. (1999). The Motivation to Work, $3^{\text {rd }}$ edition, Transaction, Publishers, New Brunswick.

[31] Avey, J. B., Wernsing, T. S., \& Luthans, F. (2008). Can positive employees help positive organizational change? Impact of psychological capital and emotions on relevant attitudes and behaviors. The journal of applied behavioral science, 44(1), 48-70. 
[32] Chow, I. H. S., \& Liu, S. S. (2009). The effect of aligning organizational culture and business strategy with HR systems on firm performance in Chinese enterprises. The International Journal of Human Resource Management, 20(11), 2292-2310.

[33] Noe, R. A., Hollenbeck, J. R., Gerhart, B., \& Wright, P. M. (2017). Human resource management: Gaining a competitive advantage. New York, NY: McGraw-Hill Education.

[34] Owusu-Ansah, K. (2014). The impact of employees performance. The case of Ghana Ports and Harbour Authority (GPHA). Unpublished work.

[35] Ta Taber, C. S., \& Lodge, M. (2006). Motivated skepticism in the evaluation of political beliefs. American Journal of Political Science, 50(3), 755-769.

[36] Wiley, C. (1997). What Motivates Employees According to Over 40 years of Motivation Surveys, International Journal of Manpower, 18(3), Pg. 263-280.

[37] Dobre, O. I. (2013). Employee motivation and organizational performance. Review of applied socioeconomic research, 5(1).

[38] Ghazanfar, F., Chuanmin, S., Khan, M. M., \& Bashir, M. (2011). A study of relationship between satisfaction with compensation and work motivation. International Journal of Business and Social Science, 2(1).

[39] Bob, N. (2011). Making Employee Suggestions Count, Journal of Personal Management 17, $20-41$.

[40] Aktar, S., Sachu, M. K., \& Ali, M. E. (2012). The impact of rewards on employee performance in commercial banks of Bangladesh: An empirical study. IOSR Journal of Business and Management, 6(2), 9-15.

[41] Markova, G., \& Ford, C. (2011). Is money the panacea? Rewards for knowledge workers. International Journal of Productivity and Performance Management, 60(8), 813-823.

[42] Palmer, E., \&Eveline, J. (2012). Sustaining low pay in aged care work. Gender, Work \& Organization, 19(3), 254-275.

[43] Dixit, A. (2002). Incentives and organizations in the public sector: An interpretative review. Journal of human resources, 37(4), 696-727.

[44] Humphrey, R. H., Pollack, J. M., \&Hawver, T. (2008). Leading with emotional labor. Journal of managerial psychology, 23(2), 151-168.

[45] McLeod, S. (2007). Maslow's hierarchy of needs. Simply psychology, 1.

[46] Chalfant, H. P., \& LaBeff E. (1988). Understanding people and social life: Introduction to Sociology. New York: West Publishing Company.

[47] Elijah-Mensah, A. (2010). Impact of motivation on venture growth. A Grounded Theory Approach on Women Entrepreneurs in Ghana's Tourism Industry. Ghana: the global networked management school.

[48] Denscombe, M. (2014). The good research guide: for small-scale social research projects. McGraw-Hill Education (UK).

[49] Beatty, P. C., \& Willis, G. B. (2007). Research synthesis: The practice of cognitive interviewing. Public opinion quarterly, 71(2), 287-311.

[50] Oppenheim, A. N. (2000). Questionnaire design, interviewing and attitude measurement. Bloomsbury Publishing.

[51] Fairweather, J., \&Rinne, T. (2012). Clarifying a basis for qualitative generalization using approaches that identify shared culture. Qualitative Research, 12(4), 473-485.

[52] Bahari, S. F. (2010). Qualitative versus quantitative research strategies: contrasting epistemological and ontological assumptions. SainsHumanika, 52(1).

[53] Polit, D. F., \& Beck, C. T. (2010). Generalization in quantitative and qualitative research: Myths and strategies. International journal of nursing studies, 47(11), 1451-1458

[54] Seifert, C. M., Chapman, L. S., Hart, J. K., \& Perez, P. (2012). Enhancing intrinsic motivation in health promotion and wellness. American Journal of Health Promotion, 26(3), 1-12.

[55] Osabiya, B. J. (2015). The effect of employees motivation on organizational performance. Journal of Public Administration and Policy Research, 7(4), 62-75.

[56] Dalton, M. (2017). Men who manage: Fusions of feeling and theory in administration. Routledge.

[57] Herzberg, F. (2008). One more time: how do you motivate employees?. Harvard Business Review Press.

[58] Kawaguchi, D. (2002). Compensating wage differentials among self-employed workers: Evidence from job satisfaction scores.

[59] Podgursky, M. J. (2003). Fringe benefits: There is more to compensation than a teacher's salary. Economics publications (MU). 
[60] Hong, E. N. C., Hao, L. Z., Kumar, R., Ramendran, C., \&Kadiresan, V. (2012). An effectiveness of human resource management practices on employee retention in institute of higher learning: A regression analysis. International journal of business research and management, 3(2), 60-79.

[61] McGuire, J., Dow, S., \&Argheyd, K. (2003). CEO incentives and corporate social performance. Journal of Business Ethics, 45(4), 341-359.

Citation: E. Ohene Afriyie. et al "The Effect of Compensation on Employees' Performance: A Case of a Technical University in Ghana" International Journal of Managerial Studies and Research (IJMSR), vol 8, no. 6, 2020, pp. 44-54. doi: http://dx.doi.org/10.20431/2349-0381.0806005.

Copyright: (C) 2020 Authors. This is an open-access article distributed under the terms of the Creative Commons Attribution License, which permits unrestricted use, distribution, and reproduction in any medium, provided the original author and source are credited. 